\title{
Strategi Komunikasi Pemerintah Indonesia dalam Penanganan COVID-19 pada Majalah TEMPO Edisi Maret-Juli 2020
}

\author{
Fadjarini Sulistyowati ${ }^{1}$, Nina Uswatun Hasanah ${ }^{2}$ \\ ${ }^{1,2}$ Prodi Ilmu Komunikasi STPMD “APMD” Yogyakarta \\ Email: dzarbela@yahoo.co.id
}

Diterima : 06 Juni 2021

Disetujui : 31 Juli 2021

Diterbitkan : 15 Agustus 2021

\begin{abstract}
Abstrak
Dalam mengantisipasi Pandemi Covid-19, kebijakan pemerintah perlu dikomunikasikan ke masyarakat dengan jelas dan transparan. Penyampaian kebijakan yang tidak strategis akan memberikan dampak dalam komunikasi publik. Komunikasi publik yang tidak terencana dengan baik akan mengakibatkan kepanikan dan ketidakpercayaan masyarakat. Komunikasi publik terbangun melalui strategi komunikasi yang tepat. Pada awal adanya Pandemi Covid-19 pemerintah perlu menyusun strategi komunikasi yang tepat sehingga penyampaian kebijakan dapat terencana dan informasi dapat tersampaikan ke masyarakat. Strategi komunikasi menentukan suatu rancangan pesan yang dibuat sehingga dapat memberikan kejelasan kebijakan pemerintah dalam mengatasi pandemi Covid-19. Media menjadi penyampai pesan dari pemerintah ke masyarakat. Media mampu mengkonstruksikan strategi komunikasi pemerintah dalam penanganan Pandemi Covid-19 melalui pemberitaan yang disampaikan. Dengan framenya media membangun persepsi masyarakat atas pemberitaan tersebut. Penelitian ini mendeskripsikan frame Majalah Tempo terkait strategi komunikasi pemerintah dalam penanganan Pandemi Covid 19. Metode yang digunakan adalah teknik analisis framing dengan analisis dari Entmann. Pengumpulan berita dilakukan sejak bulan awal Maret - Akhir Juli 2020. Dari berita-berita tersebut dipilih berita-berita yang terkait dengan strategi komunikasi pemerintah terkait penanganan Covid-19.. Hasil penelitian menunjukkan Majalah Tempo menframe bahwa pemerintah belum menerapkan strategi komunikasi dalam penanganan Covid-19, baik pada awal pandemi Covid-19, masa pelaksanaan PSBB (Pembatasan Sosial Berskala Besar) dan masa normal baru. Majalah Tempo mampu memberikan kontrol terhadap kebijakan yang berkaitan dengan strategi komunikasi pemerintah dalam penanganan Covid-19.
\end{abstract}

Kata kunci: Strategi Komunikasi, Framing, Tempo, Covid-19.

\begin{abstract}
In anticipating COVID-19 pandemic, policies directed by the government needs to be communicated to the people with clarity and transparency. Unplanned communications will lead to consequences in the public sector. Public communication that is not planned carefully will cause panic and distrust in society.. In the beginning of Covid-19 pandemic, the government must construct precise coomunication strategies in order to convey structured policies and information to society. Communication strategies includes the contents of the messages that are going to be conveyed in order to provide clarities regarding government's policies to address Covid-19 pandemic. The media works as a tool to convey messages from the government to the society by constructing government's communication strategies in addressing covid-19 using the news. Media can create perceptions
\end{abstract}


withing society in regards to the news. This research is being done to understand the frame of Tempo Magazine in government's communication strategies to handle COVID-19 pandemic. Analysis technique using analysis by Entmann. News collection is being done from early March to late July 2020. News related to the government's communication strategies to handle COVID-19 pandemic are being selected. Results show that government is not ready yet to implement accurate communication strategies in handling COVID-19, from the early COVID-19 pandemic, PSBB (Pembatasan Sosial Berskala Besar) to the new normal era. Tempo magazine can provide control towards policies that are relevant to government's communication strategies in dealing with Covid19

Keywords: Strategies Komunikasi, Framing, Tempo, Covid-19.

\section{PENDAHULUAN}

Banyak negara mengalami kebingungan dalam mengambil kebijakan saat pandemi Covid-19. Setiap negara mencoba mengambil kebijakan paling tepat untuk menghambat sekaligus mengatasi penyebaran virus Corona. Cina, Singapura, Taiwan dan Korea Selatan merupakan contoh negara yang memiliki penanganan Covid-19 dengan cukup baik, bukan hanya karena mereka telah terlatih menangani kasus virus seperti Flu Burung dan SARS tetapi karena negara-negara tersebut mempunyai kemampuan dalam melakukan perencanaan dan koordinasi kelembagaan dalam kerangka kesigapan emergensi nasional, ketersediaan data dan informasi secara akurat, dan mampu memanfaatkan teknologi informasi serta adanya pedoman kebijakan yang strategis dalam penanganan penyakit menular, (Muda, 2020).

Covid-19 telah dinyatakan oleh WHO sebagai pandemi pada tanggal 11 Maret 2020, (Mona, 2020). Situasi ini, menyebabkan kecemasan dan ketidakpastian di seluruh dunia, setiap negara menanggapi dan memiliki kebijakan yang berbeda (Limilia \& Pratamawaty, 2020)(Sabir \& M. Phil, 2016). Kecemasan ini juga dihadapi oleh masyarakat yang tidak siap menghadapi pandemi ini baik secara fisik maupun psikis, (Sabir \& M. Phil, 2016), (Fitria \& Ifdil, 2020). Namun, salah satu kunci penting dalam penanganan Covid-19 adanya sikap dasar dan penghargaan atas keterbukaan informasi yang akan memunculkan partisipasi publik (Sulhan, 2020).

Dalam mengantisipasi Pandemi Covid-19, seharusnya pemerintah perlu menyampaikan kebijakan secara jelas dan transparan ke masyarakat. Komunikasi publik yang tidak terencana dengan baik akan mengakibatkan kepanikan dan ketidakpercayaan masyarakatnya. Komunikasi publik terbangun dengan adanya strategi komunikasi yang tepat. Beberapa negara Eropa mengalami kegagalan dalam memutuskan kebijakan, akibatnya beberapa negara seperti Italia dan Spanyol tak berdaya melawan virus Corona. Amerika Serikat merupakan negara besar yang termasuk gagal dalam menerapkan strategi komunikasi yang tepat, apalagi di masa awal Presiden Trump menganggap Covid-19 bukan masalah serius.

Rogers memberi batasan pengertian strategi komunikasi, Sebagai rancangan yang dibuat untuk mengubah perilaku manusia terutama dalam skala lebih besar melalui transfer ide-ide baru (Cangara, 2017). Sedangkan Middleton berpendapat, keberhasilan strategi komunikasi akan didukung oleh semua elemen komunikasi mulai dari komunikator, pesan, 
saluran (media), penerima sampai pada efek untuk mencapai tujuan komunikasi. yang optimal (Cangara, 2017). Strategi komunikasi dapat dilaksanakan bila proses komunikasi dimaknai sebagai upaya pengiriman dan penerimaan pesan dari dua pihak. Tentunya, dua pihak tersebut memiliki kepentingan dan pengetahuan untuk saling dipertukarkan, sehingga semua yang terlibat dalam proses komunikasi menjadi pertimbangan dalam strategi komunikasi (Bungin, 2015).

Kemantapan dalam memilih strategi komunikasi adalah langkah krusial yang harus dipertimbangkan secara cermat dalam perencanaan komunikasi, ketika salah memilih maka tidak akan memeroleh hasil yang memuaskan bahkan bisa menimbulkan kerugian yang fatal, (Wijaya, 2015). Penetapan strategi komunikasi tidak lepas dari elemen komunikasi, seperti yang disampaikan Harold D. Laswell, bahwa cara untuk berkomunikasi dengan menjawab pertanyaan "Who Says What In What Channel To Whom With What Effect", (Effendy, 2000). Dalam menyusun strategi pada perencanaan komunikasi perlu memperhatikan langkah-langkah: 1) Memilih komunikator; 2) Mengetahui target sasaran/khalayak; 3) Menggunakan pesan yang tepat; 4) Pemilihan media dan 5) Mengkaji ulang dampaknya (Wijaya, 2015).

Indonesia merupakan salah satu negara yang terlambat mengatisipasi pandemi Covid-19. Hal ini tampak dari terlambatnya kebijakan awal yang dikeluarkan pemerintah terkait virus Corona, pemerintah bahkan tidak berupaya keras untuk mencegah masuknya virus. Pemerintah kurang cepat bahkan terkesan lamban, serta tidak memperhitungkan dampak wabah sejak awal. Muncul kesan saling lempar tanggung jawab antar lembaga pemerintah di awal pandemi (Fadhal, 2020). Pendapat yang berbeda disampaikan oleh Sulhan (2020) bahwa pemerintah telah melakukan proses komunikasi publik semaksimal mungkin terkait Covid-19, namun publik melihat semua upaya itu tidak cukup maksimal untuk dipandang sebagai langkah strategis mengatasi pandemi (Sulhan, 2020)

Beberapa ahli berpendapat, "Indonesia mengalami krisis kebijakan dalam penanganan Covid-19, terutama pada masa Golden Moment atau awal-awal pandemi Covid-19 yang dianggap sebagai waktu yang tepat untuk mempersiapkan diri dan awal tanggap darurat" (Mas'udi \& Winanti, 2020). Ketika pandemi Covid-19 mulai dirisaukan banyak negara di dunia yakni dari awal Januari sampai bulan Februari, pemerintah Indonesia tidak menunjukkan respons dan sikap antisipatif. Bahkan pada saat negara-negara lain berupaya mencegah penyebaran COVID-19 dengan memberlakukan pembatasan perjalanan, Indonesia membuka pintu bagi wisatawan agar datang berkunjung. Pada saat itu, pemerintah belum merencanakan strategi penyampaian informasi tentang Covid-19 ke masyarakat dan mengalokasikan anggaran untuk sosialisasi dan pencegahan penyebaran virus tersebut padahal sosialisasi kepada masyarakat sebagai upaya pencegahan penyebaran virus adalah hal yang mendasar, di sisi lain pemerintah bahkan berencana membelanjakan anggaran untuk kampanye daring pariwisata (Almuttaqi, 2020). Selain itu, pemerintah sejak awal lebih memfokuskan pada kepentingan ekonomi dan stabilitas politik sebagai akibat dampak pandemi bukan pada penanganan Covid-19 itu sendiri. Padahal upaya menyusun strategi dan 
perencanaan kebijakan perlu segera dilakukan, pemerintah tidak bisa hanya mementingkan kepentingan ekonomi. Pemerintah sebaiknya tidak hanya memikirkan satu sektor ekonomi saja dan perlu memprioritaskan kesehatan untuk ditangani terlebih dahulu. Hal ini seperti sisi mata uang manakah yang menjadi prioritas kesehatan atau ekonomi atau sebaliknya, (Cahyono, 2020).

Berbagai upaya dan strategi komunikasi pemerintah dalam menyampaikan kebijakan publik akan tampak dalam pemberitaan media. Media massa sangat berperan dalam memberikan kontrol terhadap kebijakan yang dijalankan negara dalam mengatasi krisis. Informasi berbagai kebijakan dari pemerintah disampaikan media massa ke masyarakat untuk memberikan ketenangan pada masyarakat. Media massa harus dapat menjalankan empat fungsi: informasi, pendidikan, kontrol sosial dan hiburan, di samping media massa juga harus menjalankan fungsi ekonomi. Hal ini sesuai dengan amanat UU Pers No. 40/1999 tentang peran pers yakni: "Untuk memenuhi hak masyarakat untuk mengetahui, mendorong terwujudnya nilai-nilai demokrasi, supremasi hukum, hak asasi serta kebhinekaan, mendorong pengembangan pendapat umum atas dasar informasi yang akurat dan melakukan pengawasan serta kontrol sosial". Pers memiliki hak dan tanggung jawab, ia berhak untuk mengkritik pemerintah dan lembaga-lembaga lain, tetapi ia bertanggung jawab terhadap terselenggaranya demokrasi dengan menginformasikan kebenaran ke publik dan membuka "telinga" terhadap kebutuhan dan kepentingan masyarakat (Dominick, 2009).

Keberadaan jurnalisme tetaplah dianggap penting dalam suatu negara, pemberitaan media akan mendorong kontrol terhadap kebijakan pemerintah. Sehingga untuk itu, jurnalisme tetap harus berpegang teguh pada elemen-elemen jurnalisme yang disampaikan 1) Jurnalis harus berpihak pada kebenaran; 2) Loyalitas jurnalisme pada publik; 3) Mentaati verifikasi ; 4) Jurnalis tidak boleh berpihak; 5) Jurnalis ikut memantau kekuasaan; 6) Memberikan ruang untuk kritik dan komentar publik; 7) Menjadikan hal yang penting menjadi menarik namun tetap relevan; 8) Pemberitaan disampaikan secara komprehensif dan proporsional; 9) Jurnalis bersandar pada hati nurani dalam menyampaikan berita serta yang merupakan elemen terakhir yang munculnya karena perkembangan media digital, yakni perlunya hak dan tanggung jawab dalam penyampaian berita (Kovach \& Resintiel, 2001).

Media tidaklah saluran yang bebas, media memiliki kemampuan untuk menyusun realitas sesuai dengan pandangan jurnalis, bias dan pemihakannya (Eriyanto, 2011). Media sendiri dianggap sebagai pranata sosial yang dinamikanya dipengaruhi oleh berbagai kepentingan baik dari dalam maupun luar institusi (Dyna S., 2019), Untuk mengetahui keberpihakan media maka harus tahu isi media. Isi media akan menunjukkan kemanakah media berpihak karena isi media merupakan basis dari pengaruh media, isi media merupakan kajian komunikasi yang penting untuk memahami adanya fenomena yang tersembunyi (Krisdinanto, 2014).

Menurut Pamella dan Reese:

"Media bukanlah ruang hampa, ada faktor internal dan eksternal terhadap isi media, faktor internal yang memengaruhi isi media terbagi dalam beberapa level yakni: 1) individu sebagai pekerja media (individual level); 2) pengaruh rutinitas media (media 
routines level); 3) organisasi media (organizational media level) sedangkan faktor eksternal yang memengaruhi isi media dibagi dalam 1) level ekstra media misalnya pemodal, partai politik dan lain-lain dan 2) level ideologi”, (Pamella J. \& Reese, 1996).

Teori ini menggambarkan bahwa ruang berita bukanlah ruang hampa, bebas kepentingan dan sebagainya sehingga pesan yang disampaikan dari media tidaklah tepat sesuai realitas peristiwa itu sesungguhnya namun realitas yang sudah medapat pengaruh baik dari faktor internal maupun eksternal media.

Pesan yang disampaikan media berdasarkan atas liputan jurnalis. Dari beberapa peristiwa yang terjadi, melalui mekanisme keredaksionalan dipilih peristiwa yang dianggap perlu untuk diberitakan sebagai informasi penting yang harus diketahui khalayak. Dalam konteks ini, media berperan penting dalam pembentukan public opinion dan menjadi media penyampai informasi pemerintah ke publik terutama untuk menyampaikan informasi terkini dalam pengendalian dan pencegahan Covid-19. Fungsi pengawasan media berperan dalam penentuan agenda politik terutama yang berkaitan dengan kontrol terhadap kebijakan publik, hal ini sesuai hasil penelitian Anggraini dan Saptatia pada peran media di Inggris dan Jerman dalam menangani COVID-19 (Anggraini \& Saptatia, 2021). Sajian berita di media massa adalah hasil mekanisme kerja redaksi, G.J. Aditjondro menjelaskan, framing adalah metode penyajian realitas yang memberikan kemungkinan suatu kejadian yang sebenarnya tidak diingkari melainkan dibelokkan secara halus dengan memberikan perhatian pada aspek tertentu saja (Maria et al., 2020).

Isu pemberitaan dan informasi Covid-19 menjadi salah satu tema yang menarik untuk diteliti. Beberapa penelitian terkait dengan analisis berita tentang Covid-19 dilakukan. Penelitian framing pada Harian Kompas dalam membingkai isu Covid-19 sebelum pemberlakuan pandemi menunjukkan frame Kompas dalam menekankan pentingnya persepsi publik untuk memahami adanya risiko kesehatan (Wibhisono, 2020). Penelitian framing pada media massa di Inggris dan Jerman dalam menyajikan informasi penyebaran Covid-19 dan dan krisis kesehatan pada dua negara. Hasil penelitian menunjukkan adanya perbedaan bingkai media, media Inggris lebih menframe adanya perubahan perilaku masyarakatnya di masa pandemi Covid-19 sedangkan media Jerman lebih menframe pada akibat pandemi Covid-19 terhadap faktor ekonomi dan kesehatan di negara tersebut (Anggraini \& Saptatia, 2021).

Penelitian berikutnya terkait dengan Covid-19 yakni penelitian oleh Limilia dan Pratamawaty, yang memetakan pencarian informasi COVID-19 pada bulan Januari-Maret 2020 melalui Google Trends dan membandingkan dengan informasi yang disampaikan oleh situs Kementerian Kesehatan, metode yang digunakan adalah deskriptif kuantitatif, (Limilia \& Pratamawaty, 2020). Selanjutnya, penelitian framing oleh Handriastuti pada pemberitaan PSBB di SuaraSurabaya.net dan Kompas.com, pada edisi 8-9 Juni 2020, hasil riset menunjukkan frame kedua media lebih memfokuskan pada sosok Gubernur Jawa Timur (Handriastuti et al., 2020).

Pandemi Covid-19 menjadi tema yang signifikan untuk diangkat dalam penelitian karena munculnya berbagai permasalahan dari peristiwa tersebut. Berbeda dengan penelitian terdahulu, salah satu hal yang penting untuk dilihat adalah strategi komunikasi yang 
dilakukan pemerintah dalam penanganan Covid-19. Sebagai bagian dari penyampai pesan, media berperan dalam menjalin komunikasi dari pemerintah ke publik dan menangkap aspirasi dari masyarakat ke pemerintah sehingga frame yang dilakukan media akan memengaruhi opini publik. Analisis framing dapat mengakibatkan pergeseran pemahaman pembaca terhadap berita (Kasim \& Adibah Ismail, 2018) (Palupi \& Irawan, 2020). Untuk itu penelitian ini akan melihat bagaimana frame Majalah Tempo terkait strategi komunikasi pemerintah dalam penanganan Covid-19. Pemilihan Majalah Tempo dengan asumsi media ini merupakan media yang cukup kritis dalam menilai kebijakan pemerintah. Tempo memiliki rekam jejak sebagai media yang independen dalam mengawal kebijakan pemerintah sejak jaman Orde Baru (Steele, 2007).

\section{METODOLOGI PENELITIAN}

Metode yang digunakan adalah metode kualitatif dengan analisis framing. Framing merupakan teknik analisis untuk memahami cara pandang jurnalis dalam melihat peristiwa di lapangan dan serta perspektif media dalam memilih isu dan menulis berita. Cara pandang ini akan menentukan pilihan atas fakta yang perlu diambil atau dikurangi bahkan dihilangkan serta fakta mana yang lebih banyak diberitakan dan bagian mana yang dihilangkan serta bagaimana isi berita diarahkan,. (D’Angelo \& Kuypers, 2009).

Framing pada hakekatnya sebagai penekanan definisi, penjelasan, evaluasi dan memberikan rekomenasi pada suatu wacana yang menekankan kerangka berfikir tertentu (Neviati, 2018) (Zulaikha, 2019). Analisis dilakukan dengan analisis Framing dari Entmann sebagai langkah untuk mengungkapkan realitas pemberitaan Majalah Tempo dengan empat level seperti bagan di bawah ini:

\begin{tabular}{ll}
\hline Define Problems & Mendefinisikan suatu permasalahan \\
& Bagaimana melihat suatu suatu peristiwa? Dimaknai \\
& sebagai apa? \\
\hline Diagnose Causes & Memperkirakan sumber permasalahan \\
& Adanya peristiwa tersebut memperlihatkan sebagai \\
& apa? Apakah sebagai penyebabnya? Atau siapa sebagai \\
& penyebab masalah? \\
\hline Make moral Judgment & Keputusan moral apakah yang dimunculkan sebagai \\
& upaya melegitimasi tindakan? \\
\hline
\end{tabular}

Treatment Recommendation

Penyelesaian apakah yang disampaikan media atau rekomendasi apakah yang ditawarkan media? 
Berdasarkan dari pengumpulan berita yang dilakukan sejak bulan awal Maret - akhir Juli 2020 dipilih berita-berita yang terkait dengan strategi komunikasi pemerintah terkait penanganan Covid-19. Ada tujuh edisi Majalah Tempo pada bulan-bulan tersebut yang menyajikan liputan khusus pandemi Covid-19 dari tujuh edisi tersebut ada empat berita yang terkait dengan strategi komunikasi pemerintah dalam penanganan Covid-19. Berita dipilih dalam tiga kategori yang sesuai dengan periode penanganan Covid-19 di Indonesia yakni:

1. Berita terkait strategi komunikasi pemerintah pada periode awal Pandemi Covid19

2. Berita terkait strategi komunikasi pemerintah pada periode penerapan PSBB (Pembatasan Sosial Berskala Besar)

3. Berita terkait strategi komunikasi pemerintah pada periode new normal

Pada penelitian ini maka ada empat berita yang dianalisis:

\begin{tabular}{|c|c|c|c|c|c|}
\hline No & $\begin{array}{l}\text { Pembagian } \\
\text { tahapan strategi }\end{array}$ & Edisi & Tanggal & Judul berita & Cover \\
\hline 1 & $\begin{array}{lr}\text { Strategi } & \text { komunikasi } \\
\text { pemerintah } & \text { pada } \\
\text { awal } & \text { pandemi } \\
\text { Covid-19 } & \end{array}$ & $\begin{array}{l}\text { Tergagap } \\
\text { Corona }\end{array}$ & $\begin{array}{l}\text { 9-15 Maret } \\
2020\end{array}$ & $\begin{array}{l}\text { Lobi Corona di } \\
\text { Jenewa }\end{array}$ & \\
\hline 2 & $\begin{array}{l}\text { Strategi komunikasi } \\
\text { pemerintah pada } \\
\text { periode penerapan } \\
\text { PSBB }\end{array}$ & $\begin{array}{l}\text { "Compang- } \\
\text { Camping } \\
\text { Corona }\end{array}$ & $\begin{array}{l}16-22 \\
\text { Maret } 2020\end{array}$ & $\begin{array}{l}\text { Menyangkal Krisis } \\
\text { Menuai Bencana }\end{array}$ & \\
\hline 3 & $\begin{array}{l}\text { Strategi komunikasi } \\
\text { pemerintah pada } \\
\text { periode penerapan } \\
\text { PSBB }\end{array}$ & $\begin{array}{l}\text { Compang- } \\
\text { Camping } \\
\text { Corona }\end{array}$ & $\begin{array}{l}16-22 \\
\text { Maret } 2020\end{array}$ & $\begin{array}{l}\text { Akrobat tanpa } \\
\text { Kabar dari Pusat }\end{array}$ & \\
\hline 4 & $\begin{array}{l}\text { Strategi komunikasi } \\
\text { pemerintah pada } \\
\text { periode new normal }\end{array}$ & $\begin{array}{l}\text { Simalakama } \\
\text { Normal } \\
\text { Baru }\end{array}$ & $\begin{array}{ll}1-7 & \text { Juni } \\
2020 & \end{array}$ & $\begin{array}{l}\text {.Main Api New } \\
\text { Normal }\end{array}$ & \\
\hline
\end{tabular}

Tabel 2. Berita-berita yang Dianalisis

(Sumber: data penelitian) 


\section{HASIL DAN PEMBAHASAN}

Pada periode awal pandemi Covid-19 yakni sebelum adanya pengumuman pemerintah untuk menetapkan PSBB, Majalah Tempo mengulas pada satu edisi dengan judul "Tergagap Corona". Cover Majalah Tempo Presiden Joko Widodo bersama dengan Menteri Kesehatan Terawan Hadi Putranto seolah tersandera masker yang dipakai bersama. Gambar sampul ini mengindikasikan ketidaksiapan pemerintah dalam menghadapi pandemi Covid-19 sesuai judulnya "Tergagap Corona".

Pada berita utama "Lobi Corona di Jenewa", Majalah Tempo memberitakan ketidakterbukaan pemerintah dalam menginformasikan dan penanganan penyebaran virus Corona. Hal ini menurut Tempo dipertanyakan baik masyarakat dalam negeri maupun dunia internasional. Sehingga WHO pun menegur pemerintah Indonesia dan akhirnya Menteri Luar Negeri menemui langsung Direktur Jendral WHO Tedros Adhanom di Jenewa Swiss, di sela-sela pertemuan sidang hak asasi PBB tanggal 25 Februari 2020.

Tempo menyajikan berbagai simpang siur komunikasi dan informasi antara berbagai pihak yang terkait penanganan Covid-19. Misalnya, pada alenia kedua disebutkan "Presiden Jokowi mengklaim pendeteksian dua pasien itu merupakan hasil penelusuran pemerintah setelah mendapat informasi bahwa warga Jepang yang singgah ke Indonesia terpapar Covid19”. Di lain pihak, kedua pasien merasa mereka melapor atas kesadaran sendiri bukan karena hasil pelacakan pemerintah. Jumpa pers yang digelar pemerintah untuk mengumumkan pasien 1 dan 2 juga menimbulkan polemik karena kementrian kesehatan sendiri belum mendapat tembusan informasi tersebut bahkan pihak RS belum menyampaikan secara resmi tentang terkonfirmasi Covid-19 ke pasien, ("Lobi Corona di Jenewa," 2020). Dari simpang siur informasi ini menunjukkan pemerintah belum memberikan informasi secara transparan kepada publik, padahal dalam model komunikasi risiko dalam penanganan bencana dibutuhkan adanya truth-objective world, legitimacy-social world, auhtenticty-inner world yakni apa yang disampaikan adalah benar, teoritis ilmiah, apa yang dikatakan adalah sah, praktis, normatif sosial dan disampaikan dengan jujur berbasis pada keyakinan, emansipatoris, individu dan kelompok, (Drottz-Sjoberg \& Britt-Marie, 2012).

Berita ini menunjukkan keraguan pihak luar dan dalam negeri atas kemampuan pemerintah dalam mendeteksi keberadaan Virus Covid-19. Beberapa narasumber yang diwawancarai Tempo menguatkan hal ini baik dari WHO, beberapa peneliti dari Harvard University USA dan perwakilan Bidang Penelitian Fundamental Lembaga Biologi Mokuler Eiijkman, Herawati Sudoyo. Keraguan tersebut muncul karena belum adanya transparansi informasi terkait sejumlah orang yang dideteksi virus Corona.

Majalah Tempo menilai Menteri Kesehatan Terawan Agus Putranto kurang memiliki kemampuan berkomunikasi dalam menanggapi kebijakan covid-19. Beberapa pesan yang disampaikan Menkes menjadi rumor di media massa misalnya ketika beliau menganjurkan agar masyarakat supaya berdoa dan shalat Istigasah untuk menangkal virus Corona. Menurut Tempo, hal ini juga membuat Presiden gusar seperti yang disampaikan dalam berita tersebut "Istana sesungguhnya sudah gusar terhadap cara Kementrian Kesehatan menjawab keraguan tentang kehadiran Corona",("Lobi Corona di Jenewa," 2020). Ketidakpercayaan Presiden terhadap Menkes terindikasi ketika Presiden akhirnya mencoba menanyakan sendiri terkait informasi terbaru Corona dan protokol penanganannnya ke 
Kemenkes bahkan akhirnya Istana merancang sendiri sejumlah protokol untuk menghadapi Covid-19. Dalam hal ini bila dianalisis dengan komponen dalam strategi komunikasi maka peran Menteri Kesehatan dianggap kurang memiliki kapasitas sebagai komunikator, padahal komunikator berperan mengendalikan semua aktivitas komunikasi (Cangara, 2017)(Limilia \& Pratamawaty, 2020). Gaya komunikasi Menkes Terawan, dianggap kurang tepat sehingga mengakibatkan turunnya kepercayaan masyarakat terhadap kredibilitas pemerintah, (Laksmiwati \& Lukitawati, 2020).

Dari hasil analisis Entman, yang menjadi define problems adalah kesimpangsiuran informasi terkait Covid-19 dan kelambanan pemerintah dalam mengantisipasi penyebaran virus Covid-19. Kesimpangsiuran komunikasi menunjukkan tidak terbangunnya strategi komunikasi yang baik untuk menyampaikan informasi ke masyarakat maupun komunikasi antar lembaga pemerintahan sendiri. Pemerintah dianggap tergagap sesuai dengan judul headline liputan edisi ini. Gagap menunjukkan adanya ketidakmampuan dalam berkomunikasi. Strategi komunikasi tidak terbangun dengan baik karena Menteri Kesehatan sebagai komandan melawan virus di lapangan tidak berupaya menyusun pesan komunikasi yang tepat. Bahkan menurut Tempo menteri kesehatan lebih menganggap remeh terhadap wabah tersebut. Permasalahan simpang siurnya informasi sesaui dengan pendapat Fakhuroji yang menyatakan kesimpangsiuran informasi seharusnya diantisipasi sejak awal oleh pemerintah supaya dapat mengkounter informasi yang keliru dengan menyampaikan informasi yang lebih detail kepada publik (Fakhururoji et al., 2020).

Diagnose Causes dalam berita ini adalah, ketidaksiapan pemerintah terutama Menteri Kesehatan sebagai komunikator dalam penyampian informasi virus Corona ke masyarakat. Menkes yang pada awal pandemi terlanjur meremehkan wabah Corona mengakibatkan pesan yang disampaikan ke masyarakat menjadi rumor yang membingungkan. Ketidaksiapan ini mengakibatkan pemerintah tidak memiliki perencanaan komunikasi yang dapat mendukung strategi komunikasi yang tepat. Hasil diagnose causes ini menunujukkan adanya kegagalan dalam mengelola informasi untuk disampaikan dalam komunikasi publik (Farisa, 2020) (Widaningrum \& Mas'udi, 2020). Padahal prinsipnya, bila komunikasi publik dipersiapkan dengan akurat, tuntas, dan strategi yang matang, serta adanya monitoring dan evaluasi maka akan memberikan pengaruh positif pada partisipasi masyarakat, (Erda Dewi, 2021).

Make moral judgment, sesuai yang disampaikan oleh Direktur WHO Tedros Adhanom mengingatkan: "Agar tidak ada negara yang jemawa meski belum ada Corona di wilayahnya serta tidak boleh ada negara yang berasumsi mereka tidak akan memiliki kasus Covid-19. Itu adalah kesaalahan fatal", ("Lobi Corona di Jenewa," 2020). Pernyataan yang disampaikan direktur WHO menjadi pesan moral yang dibangun oleh Majalah Tempo. Pernyataan ini menyiratkan bahwa WHO sudah menyatakan setiap negara harus mempersiapkan masyarakatnya untuk mengantisipasi wabah virus Covid-19 karena ini merupakan pandemi.

Treatment recommendation yang dibangun dalam berita ini adalah meminta pemerintah bersama Menteri Kesehatan segera menyusun strategi komunikasi ke publik terkait kebijakannya dalam mengatasi penyebaran Covid-19. Pemerintah perlu memperbaiki cara penyampaian komunikasi ke publik karena beberapa permasalahan bermuara dari komunikasi. Hal ini tersirat dari alenia kedua dari bawah berita tersebut, "Nyatanya persoalan komunikasi tetap terjadi". Untuk itu, menurut Tempo perlu upaya pemerintah menetapkan strategi komunikasi yang tepat supaya permasalahan komunikasi tidak terjadi. 
Hal ini sesuai dengan pendapat Middleton, strategi komunikasi merupakan upaya mengkombinasikan komponen-komponen komunikasi baik dari penyampai pesan/ komunikator, pesan, saluran, penerima sampai efek yang dirancang untuk mencapai tujuan komunikasi yang optimal (Cangara, 2017).

\section{Frame Majalah Tempo terkait strategi komunikasi pemerintah pada periode penerapan PSBB}

Edisi Majalah Tempo ini mengangkat laporan utama dengan judul "CompangCamping Corona”. Majalah Tempo cukup kritis dalam mengulas strategi mitigasi yang dilakukan pemerintah. Pada opini redaksi, Majalah Tempo menganggap bila pemerintah tidak berupaya memperbaiki strateginya dalam mengahadapi penyebaran Corona bisa dianggap sebagai pelanggaran konstitusi, ("Opini Redaksi: Morat-Marit Menghadapi Corona," 2020). Menurut Tempo, "Pemerintah terkesan lambat dan tidak terpadu dalam menangkal wabah yang telah ditetapkan sebagai pandemi global untuk memperbaiki hal itu pemerintah harus menunjukkan usaha sungguh-sungguh sebagai upaya melindungi masyarakat Indonesia". Ada dua berita yang dianalisis; berita pertama dengan judul "Menyangkal Krisis Menuai Bencana" dan berita kedua "Akrobat Tanpa Kabar Pusat".

Pada berita "Menyangkal Krisis Menuai Bencana" diawali dengan lead yang mengkritisi pemerintah "Sikap pemerintah dalam menangani virus Corona terus menuai kritik". Dari lead tersebut Tempo memberikan kesan bahwa sampai periode penerapan PSBB kebijakan yang dilakukan pemerintah masih banyak memunculkan kritik. Kritik dari masyarakat menunjukkan negara belum mengeluarkan kebijakan yang tepat dalam penanganan Covid-19 ("Menyangkal Krisis Menuai Bencana," 2020). Untuk penanganan Covid-19 perlu adanya kekuatan itikad politik dari pemerintah dan kebijakan yang mendukung transparansi tata kelola serta pemenuhan atas hak kesehatan masyarakat, (Widaningrum \& Mas'udi, 2020).

Majalah Tempo mengkritisi kesimpangsiuran pengambilan kebijakan yang dilakukan pemerintah terkait pendataan kasus Covid-19. Hal ini dikuatkan penyampaian surat dari Dirjen WHO Tedros Adhanom Ghebreyesus yang menyampaikan surat untuk kedua kalinya, surat kali ini terkait keterbukaan dan transparansi data pemerintah dalam penanganan kasus Covid-19. "Data ini penting sebagai alat mengukur risiko yang komprehensif secara global" ujar Tedros ("Menyangkal Krisis Menuai Bencana," 2020). Menurut Tempo, kemampuan Indonesia dalam melakukan pelacakan dan deteksi kasus Corona dianggap WHO belum maksimal. Di sisi yang lain, pada masa awal penerapan PSBB, pemerintah belum sepenuhnya membuka akses data bahkan Presiden Joko Widodo menolak untuk membuka semua data ke publik, karena menurutnya hal ini akan menimbulkan keresahan dan kepanikan masyarakat,("Menyangkal Krisis Menuai Bencana," 2020).

Atas surat dari WHO, akhirnya Presiden Joko Widodo membentuk Gugus Tugas Percepatan Penanganan Covid-19 dan menunjuk Doni Monardo sebagai kepala BNPB sebagai kepala gugus tugas. Mulai adanya gugus tugas inilah Covid-19 dikategorikan 
sebagai bencana non alam dan ini menjadi awal pemberlakukan PSBB yakni Pembatasan Sosial Berskala Besar.

Dari hasil analisis Entman, define problems berita ini menunjukkan kebijakan yang dikeluarkan pemerintah dalam menangani kasus Corona tidak henti menuai kritik baik dari dalam maupun luar negeri. Bahkan sikap pemerintah masih bersikukuh bahwa pandemi bukan menjadi krisis di Indonesia. Dari judul berita ini, Majalah Tempo menframe bahwa menyangkal krisis akan menuai bencana yang lebih besar. Penyampaian pesan pemerintah yang berupaya menenangkan masyarakat dengan menyangkal adanya krisis bertolak belakang dengan realitas yang ada di masyarakat. Masyarakat sudah mulai resah dengan berbagai pernyataan pemerintah yang tidak konsisten. Sejumlah kritikan disampaikan baik dari WHO maupun kelompok-kelompok masyarakat dalam negeri. Ketidakkonsistenan pemerintah dalam menyampaian informasi dan komunikasi ke publik menunjukkan tidak adannya perencanaan strategi komunikasi yang baik. Beberapa kebijakan yang diambil menjadi tidak optimal misalnya dalam permasalahan data, karena tidak ada kebijakan alur informasi yang jelas bagaimana penanganan data penyebaran virus Covid-19 akhirnya informasi ini membingungkan rumah-rumah sakit daerah. Kemudian, kasus pengadaan alat uji Covid-19. Tidak adanya komunikasi yang terintegrasi mengakibatkan beberapa lembaga dalam menyampaikan informasi ke media berbeda-beda dan hal ini tentunya membingungkan masyarakat.

Diagnose Causes, pemerintah khususnya Presiden belum mengakui Pandemi Covid19 sebagai krisis. Presiden Joko Widodo menolak penyebutan krisis untuk menghindari kepanikan dalam masyarakat. Penolakan krisis ini tidak konsisten dengan realitas yang ada di masyarakat sehingga menunujukkan ketidakterbukaan sikap pemerintah. Tidak adanya keterbukaan informasi kebijakan pemerintah dan pendataan penyebaran virus mengakibatkan kesimpangsiuran arus informasi bahkan kebijakan penerapan PSBB dinilai terlambat. hal ini berbeda dengan klaim Presiden pada alenia lima, "Presiden mengklaim pemerintah bergerak cepat setelah muncul kasus baru ataupun kluster baru".

Make moral judgment dalam berita ini, pemerintah tidak perlu menyangkal adanya krisis. Dengan mengakui adanya krisis maka strategi komunikasi yang diambil merupakan solusi untuk menangani krisis tersebut. Dalam penanganan penyebaran virus Corona salah satu upaya yang harus dilakukan adalah membuka data penyebaran virus Corona ke publik. Informasi ini penting untuk agar masyarakat dapat menghindari penularan. Sehingga sikap presiden yang menolak membuka data dengan alasan mengurangi kepanikan masyarakat bukanlah alasan yang bijak dalam strategi komunikasi untuk mengendalikan virus Corona.

Treatment recommendation yang dibangun dalam berita ini, pemerintah perlu menyusun strategi komunikasi yang tepat. Salah satu upaya pemerintah yang dilakukan dengan mendengarkan saran dari para ahli epidemologi dan belajar dari negara lain dalam menanggulangi virus Corona. Untuk menyusun strategi komunikasi yang tepat, perlu adanya komunikator yang kompeten, sehingga pemerintah perlu mempertimbangkan komunikator dari sisi: 1) kredibilitas; 2) daya tarik dan 3) kekuatan, (Cangara, 2017). Siapa pun yang menjadi komunikator dalam penyampaian pesan sebaiknya memiliki kompetensi dan kekuatan yang mendukung kepercayaan masyarakat pada pemerintah. 
Pada berita ketiga dengan judul, "Akrobat tanpa kabar pusat." Lead berita ini menyampaikan tentang kurangnya koordinasi dari pusat ke daerah, yang akhirnya memicu beberapa daerah mengambil kebijakan sendiri-sendiri. Frame Majalah Tempo memberitakan tentang berbagai kemacetan informasi dan komunikasi yang terjadi baik dari pusat ke daerah atau dalam koordiansi antar departemen dan instansi. Macetnya informasi akhirnya mengakibatkan beberapa pihak memutuskan mengambil kebijakan sendiri. Misalnya dinasdinas kesehatan membentuk group WA setelah komunikasi dari kementrian kesehatan dinilai lamban dalam merespon permintaan data dari daerah. Beberapa gubernur daerah mengambil kebijakan sebelum pusat memutuskan kebijakan PSBB misalnya gubernur DKI Jakarta yang segera mengeluarkan kebijakan sebelum pemerintah pusat mengeluarkan kebijakannya, (“Akrobat Tanpa Kabar Pusat," 2020)

Define problems dalam berita ini, buruknya koordinasi dari pemerintah pusat ke daerah. Tersendatnya komunikasi dari Kementrian kesehatan dan dinas kesehatan di daerah. Bahkan Yurianto selaku juru bicara pemerintah untuk Corona mengatakan"Tak ada kewajiban pemerintah pusat menginformasikan ke daerah, yang melakukan pelacakan adalah kabupaten/kota”, ("Akrobat Tanpa Kabar Pusat," 2020). Akibat hal ini pemerintah daerah harus berakrobat untuk menanggulangi penyebaran Corona.

Diagnose Causes, kesemua hal di atas bermuara dari tersendatnya komunikasi dan lambannya pemerintah melakukan koordinasi ke daerah dalam penanganan Covid-19. Pemerintah sebagai pemutus kebijakan tidak dapat mengkoordinasikan antar berbagai instansi dan daerah. Hal ini diungkapkan oleh Walikota Solo Hadi Rudyanto, "Kepala daerah belum pernah diajak berbicara oleh pemerintah pusat mengenai penanganan Covid-19, dan tidak ada instruksi dari pusat, kami harus berkreasi sendiri ", ("Akrobat Tanpa Kabar Pusat," 2020). Demikian juga Gubernur DKI Anies Baswedan yeng bergerak cepat dengan membuat situs khusus tentang informasi Corona dengan nama situs corona.jakarta.go.id.

Make moral Judgment, keputusan moral yang dibangun dalam berita ini perlu adanya pembenahan koordinasi dan komunikasi ke daerah-daerah. Keberadaan virus Covid-19 menjadi bencana yang belum pernah dialami bangsa Indonesia namun seharusnya pemerintah bergegas menjalin komunikasi publik yang tepat dan tidak membingungkan masyarakat. Dalam kondisi krisis Covid-19, masyarakat menuntut adanya transparansi komunikasi dan informasi baik soal data pasien yang terkonfirmasi, langkah-langkah kebijakan pemerintah dan dampak sosial ekonomi (Aminulloh, 2020).

Treatment Recommendation, pemerintah pusat juga perlu mengapresiasi langkah yang diambil kepala-kepala daerah dalam memutus penyebaran virus Corona bukan mengkritiknya. Kepala daerah mengambil kebijakan sendiri-sendiri karena lambannya koordinasi dari pusat.

Dari berita ini Majalah Tempo menframe adanya kegagalan komunikasi dari pusat ke daerah dan berbagai instansi. Pemerintah pusat sebagai komunikator tidak kompeten dan dapat dipercaya oleh masyarakat. Pesan yang disampaikan masih membingungkan masyarakat. Tidak adanya komunikasi mengindikasikan kurangnya koordinasi antar pejabat pemerintah. Sesuai dengan beberapa hal ini mengindikasikan belum tersusunnya perencanaan komunikasi untuk menyusun strategi komunikasi yang tepat dalam penanganan Covid-19. 


\section{Frame Majalah Tempo terkait strategi komunikasi pemerintah pada periode new normal}

Pada edis 1-7 Juni 2020 ini Tempo mengulas tentang masa new normal dengan judul: "Simalakama Normal Baru"? Judul berita: "Main Api Normal Baru”, lead berita: "Lobi-lobi pengusaha ikut mendorong pemerintah memberlakukan normal baru di tengah pandemi Corona. Tanpa indikator yang jelas, pemerintah menetapkan puluhan daerah untuk menerapkan tatanan baru." Sesuai judul berita ini, Majalah Tempo mengkhawatirkan keputusan pemerintah untuk menerapkan new normal akan mendorong peningkatan pasien terinfeksi Covid-19,(“Main Api Normal Baru," 2020). Bahkan menurut lead berita ini, keputusan Presiden dilakukan atas desakan dari para pengusaha padahal ada amanat dari WHO tentang indikator untuk penerapan new normal.

Define problems, dalam berita ini Presiden mendorong masyarakat untuk memulai babak baru yakni hidup berdampingan dengan Covid-19 dan menerapkan new normal alias normal baru. Menurut Majalah Tempo, sikap Presiden ini didasarkan dari pernyataan WHO, bahwa virus Corona tidak mungkin hilang, sehingga Presiden meminta masyarakat untuk kembali produktif dengan menerapkan protokol kesehatan secara ketat. Dari frame Tempo, disampaikan bahwa kebijakan ini sebetulnya tidak sesuai dengan panduan WHO dalam penerapan new normal. WHO meminta adaya basis data yang akurat untuk penerapan new normal. Indonesia belum memiliki basis data yang menunjukkan penurunan jumlah penderita Covid-19 namun karena desakan kelompok tertentu maka pemerintah memutuskan kebijakan normal baru. Dari hal itu menunjukukan pemerintah tidak dapat menyusun strategi komunikasi yang tepat karena tidak ada basis data yang kuat padahal penyusunan pesan harus menyampaikan argumentasi secara logis berdasarkan fakta dan pendapat yang bisa mendukung, (Cangara, 2017).

Diagnose causesnya, dalam berita ini adanya desakan kalangan pengusaha yang tergabung Kadin, yang berkunjung ke Istana saat mendekati perayaan Idul Fitri. Ketua Umum Kadin menyampaikan menyampaikan memburuknya situasi ekonomi di tengah Pandemi Covid-19 dan keluhan para pebisnis mengenai langkah pemerintah yang hanya memprioritaskan stimulus ekonomi bagi pelaku usaha mikro dan BUMN. Adanya desakan ini menurut Majalah Tempo mendorong pemerintah menerapkan normal baru, sehingga ada indikasi keluhan para pebisnislah yang menjadi indikator penerapan new normal. Padahal pada saat itu data yang menunjukkan penurunan Covid-19 belum ada. Apalagi berdasarkan data dari Tempo, pengujian yang dilakukan Indonesia masih sangat kecil yakni 1.100 dibanding 1 juta penduduk, bila dibandingkan dengan negara lain misalnya Malaysia 16.083 per 1 juta dan Singapura 57.248 per 1 juta ("Main Api Normal Baru," 2020).

Make moral Judgment, Majalah Tempo menframe bahwa pemerintah perlu memikirkan ulang kebijakan tersebut demi keselamatan masyarakat. Frame Tempo didukung dari pendapat ahli epidemologi dan Ketua satuan tugas Covid-19 IDI. Alasan utama dari para ahli tersebut karena kondisi Indonesia yang masih berada di zona merah dengan tingkat kematian yang tinggi serta tren kenaikan kasus positif yang fluktuatif disamping upaya pemerintah untuk melakukan tes swap belum massif ("Main Api Normal Baru," 2020). 
Treatment recommendation dalam berita ini, pemerintah perlu mendengarkan pendapat ahli epidemologi dan saran pakar kesehatan lain. Presiden dalam memutuskan kebijakan normal baru mencuplik pernyataan WHO, bahwa virus Corona tidak mungkin hilang, Namun, langkah-langkah yang disampaikan WHO sebagai indikator dalam menerapkan new normal tidak diikuti, demikian juga saran dari para epidemolog. Kebijakan new normal juga menunjukkan ketidakkonsistenan pemerintah dalam menanggulangi Pandmei Covid-19. Frame Majalah Tempo ini sesuai dengan penelitian Limilia dan Pratamawaty menunjukkan pemerintah mengalami kegagalan dalam penyampaian komunikasi krisis karena ketidakonsistenan kebijakan dan informasi, (Limilia \& Pratamawaty, 2020).

Bila dilihat dari tiga tahapan di atas maka pemerintah menurut frame Majalah Tempo dianggap tidak berhasil dalam menyusun strategi komunikasi penanganan Covid-19. Hal ini sesuai dengan hasil penelitian sebelumnya yang menyorot tentang strategi komunikasi publik penanganan Covid-19 di Indonesia dari sudut pandang sosiologi komunikasi massa dan agama, pemerintah dianggap belum berhasil membangun, komunikasi publik tentang penanganan Covid-19, komunikasi pemerintah dianggap tidak sistematis dan linier diantara sesama pejabat pemerintah (Fakhururoji et al., 2020). Demikian juga hasil penelitian berikutnya, analisis isi pada beberapa surat kabar, hasil penelitian menunjukkan pemerintah belum memaksimalkan perannya dalam menggunakan strategi komunikasi secara komprehensif sehingga pemerintah tidak bisa menjadi komando dalam penanganan Covid-19 (Zahrotunnimah, 2020). Penelitian selanjutnya tentang sikap pemerintah dalam penanganan Covid-19 di Koran.tempo.co, dari hasil frame media tersebut menunujukkan sikap pesimis dan keraguan pemerintah dalam penanganan Covid-19 (Sofian \& Lestarini, 2021).

Berbeda dengan hasil penelitian yang lain, analisis framing pemberitaan Covid-19 di Kompas.com dan Tribunews.com pada 20 Maret 2020, Kompas.com cenderung menframe bahwa pemerintah telah melakukan antisipasi secara optimal sedangkan Tribunnews.com lebih menekankan unsur sensasi dalam pemberitaannya, (Hayati \& Yoedtadi, 2020). Namun, penelitian ini hanya dilakukan pada satu pemberitaan di media online yang tidak memberitakan secara mendalam.

Media massa memiliki peran strategis dalam memberikan solusi atas penanganan Covid-19 dan memberikan edukasi ke masyarakat, (Syaipudin, 2020). Hasil penelitian framing tentang pemberitan generasi mileneal dan pemerintah terkait Covid-19 di tiga media online menunjukkan media memiliki kekuasaan dalam menentukan sudut pandang atas segala kebijakan pemerintah atau memiliki perbedaan dalam penyampaian kritik ke pemerintah, (Boer et al., 2020) (Yesicha \& Irawanto, 2020) Demikian juga yang dilakukan Majalah Tempo, secara keseluruhan Majalah Tempo cukup kritis menframing strategi komunikasi pemerintah. Majalah Tempo sebagai media mencoba memberikan kontrol terhadap kebijakan yang berkaitan dengan strategi komunikasi pemerintah dalam penanganan Covid-19.

\section{PENUTUP}

Hasil penelitian analisis framing Majalah Tempo terkait strategi komunikasi pemerintah dalam penanganan Covid-19 menunjukkan pemerintah belum menerapkan strategi komunikasi yang tepat dalam penanganan Covid-19. Analisis strategi komunikasi dari frame Majalah Tempo terbagi dalam tiga periode yakni pada periode awal pandemi Covid-19, saat 
pelaksanaan PSBB dan saat new normal. Frame strategi komunikasi pemerintah pada periode awal Pandemi Covid-19 menunjukkan pemerintah belum memiliki rumusan strategi komunikasi. Pemerintah sebagai komunikator belum memiliki kesiapan dalam mengahadapi wabah Covid-19. Pemerintah di awal pandemi, menganggap virus Covid-19 tidak akan masuk ke Indonesia, sehingga tidak ada upaya antisipasi untuk mencegah virus Corona masuk Indonesia. Pada periode penerapan PSBB, frame Majalah Tempo masih mengkritisi strategi komunikasi pemerintah yang tidak terencana. Pada periode ini pemerintah telah membuat kebijakan dengan pembentukan gugus tugas penanganan Covid-19 dan menerapkan PSBB pada beberapa provinsi, kota dan kabupaten. Ketidaksiapan pemerintah ditunjukkan dengan lemahnya koodinasi dan komunikasi dengan daerah, tidak adanya transparansi dan keengganan pemerintah membuka data dan melakukan pelacakan terhadap pasien Covid-19 sehingga akhirnya menjadikan masa PSBB hanya sebagai formalitas. Demikian juga frame Majalah Tempo mengkritisi kebijakan pelonggaran yang diterapkan pemerintah didasarkan atas desakan dari para pengusaha bukan atas data yang menunjukkan penurunan pasien terkonfirmasi positif Covid-19. Keberpihakan pemerintah pada pengusaha mengindikasikan bahwa pemerintah sulit untuk mengambil kebijakan yang berorientasi pada kesehatan masyarakat sehingga strategi komunikasi yang tepat tidak terbangun dengan baik.

\section{REFERENSI}

Akrobat Tanpa Kabar Pusat. (2020). Majalah Tempo.

Almuttaqi, A. I. (2020). Kekacauan Respons terhadap COVID-19 di Indonesia. The Habibie Center Insights, 1(13), 1-7.

Aminulloh. (2020). Problem Komunikasi dan Makna di Masa Krisis Covid-19. In Nurudin, Suprihatin, A. Darmawan, M. M. Widantari, \& F. W. R. (Eds.), Komunikasi Empati dalam Pandemi Covid-19. ASPIKOM korwil Jawa Timur.

Anggraini, R., \& Saptatia, H. (2021). Peran Media Massa Inggris dan Jerman dalam Menginformasikan Pandemi COVID-19. Jurnal Riset KOMUNIKASI, 4(1), 66-80.

Boer, K. M., Pratiwi, M. R., \& Nalal Muna. (2020). Analisis Framing Pemberitaan Generasi Milenial dan Pemerintah Terkait Covid-19 di Media Online. Communicatus Jurnal Komunikasi, 4 (1), 85-104.

Bungin, B. (2015). Komunikasi Pariwisata. Prenada.

Cahyono, A. S. (2020). Implementasi Model Collaborative Governance Dalam Penyelesaian Pandemi Covid-19. Jurnal Ilmu Sosial Dan Ilmu Politik, 3(1), 83-88.

Cangara, H. (2017). Perencanaan dan Strategi Komunikasi. Rajagrafindo Persada.

D'Angelo, P., \& Kuypers, J. A. (2009). Doing news framing analysis: Empirical and theoretical perspectives. Doing News Framing Analysis: Empirical and Theoretical Perspectives, May, 1-376. https://doi.org/10.4324/9780203864463

Dominick, J. R. (2009). The Dynamics of Mass Communication: Media in The Digital Age (10 th edit). Mc Graw Hill.

Drottz-Sjoberg, \& Britt-Marie. (2012). Tools for Risk Communication. In Handbook of Risk Theory: Epiistemology, Decision, Theory, Ethics and Social Implication of Risk. Spinger.

Dyna S., H. (2019). Literasi Media Teori dan Fasilitasi. Rosdakarya.

Effendy, O. U. (2000). Ilmu Teori dan Filsafat Komunikasi. Citra Aditya Bakti.

Erda Dewi, S. A. (2021). Komunikasi Publik Terkait Vaksinasi Covid-19. Health Care Jurnal Kesehatan, 10 (1), 162-167. 
Eriyanto. (2011). Analisis Framing Konstruksi, Ideologi dan Politik Media. LKis.

Fadhal, S. (2020). Komunikasi Publik di Tengah Kritis Tinjauan Komunikasi Pemerintah. In D. H. Santoso, Nuruddin, \& F. Junaedi (Eds.), Tanggap Bencana Pandemi Covid-19 dalam Media Komunikasi dan Informasi di Masa Pandemi Covid-19. Mbridge Press.

Fakhururoji, M., Tresnawaty, B., Sumandiara, A. S. H., \& Risdayah, E. (2020). Strategi Komunikasi Publik Penanganan COVID-19 di Indonesia: Perspektif Sosiologi Komunikasi Massa dan Agama. LP2M Sunan Gunung Djati.

Farisa, F. C. (2020, April). LP3ES Catat Ada 37 Pernyataan Blunder Pemerintah soal Covid19. Kompas.Com.

Fitria, L., \& Ifdil. (2020). Kecemasan remaja pada masa pandemi Covid -19. Jurnal EDUCATIO (Jurnal Pendidikan Indonesia), 6 (1), 1-4.

Handriastuti, R., Achmad, Z. A., \& Bramayudha, A. (2020). Analisis Framing Berita Pemberitaan PSBB Surabaya Raya di Media Online Kompas.Com dan SuaraSurabaya.Net. Jurnal Ilmu Komunikasi, 10 (2), 156-176.

Hayati, H. N., \& Yoedtadi, M. G. (2020). Konstruksi Berita Covid-19 di Kompas.com dan Tribunnews.com. Koneksi, 4 ( 2 ), 243-250.

Kasim, A., \& Adibah Ismail. (2018). Framing Strategic News from The Perspective of Media Organizations in Malaysia. Malaysia Journal of Communication, 34 (1), 330344.

Kovach, B., \& Resintiel, T. (2001). Elemen-elemen Jurnalisme. Pantau.

Krisdinanto, N. (2014). Anomali dan Teori Hirarki Pengaruh terhadap Isi Media. Komunikatif Jurnal Ilmiah Komunikasi, 3, 1-18.

Laksmiwati, I., \& Lukitawati, L. (2020). Komunikasi Publik Menteri Kesehatan Terawan. Media Bina Ilmiah, 14 (12), 3581-3590.

Limilia, P., \& Pratamawaty, B. B. (2020). Google Trends and Information Seeking Trend of $\begin{array}{lllll}\text { COVID-19 in Indonesia. Jurnal ASPIKOM, } & \text { 5(2), }\end{array}$ https://doi.org/10.24329/aspikom.v5i2.741

Lobi Corona di Jenewa. (2020). Majalah Tempo, 28-31.

Main Api Normal Baru. (2020). Majalah Tempo.

Maria, F. I., Yoanita, D., \& Aritonang, A. I. (2020). Analisis Framing Pemberitaan Afiliasi Politik Basuki Tjahya Purnama di tirto.id. Kompas.com dan Liputan 6. Jurnal EKomunikasi, 8/ No 1.

Mas'udi, W., \& Winanti, P. S. (Eds.). (2020). Tata kelola penanganan Covid-19 di Indonesia, Kajian awal. Gadjahmada University Press.

Menyangkal Krisis Menuai Bencana. (2020). Majalah Tempo.

Mona, N. (2020). Konsep Isolasi Dalam Jaringan Sosial Untuk Meminimalisasi Efek Contagious (Kasus Penyebaran Virus Corona Di Indonesia). Sosial Humaniora Terapan, 2 (2), 117-125.

Muda, Z. Z. M. (2020). Komunikasi Publik Pemerintah Masa COVID-19: Telaah Kritis Sistem Informasi Publik. In W. Mas'udi \& P. S. Winanti (Eds.), Tata Kelola Penanganan COVID-19 di Indonesia: Kajian Awa (pp. 274-299). Gadjahmada University Press.

Neviati, C. . (2018). Study Case : A Tyleno Tale Makes Dies Who Consums With Framing Method. Jurnal Ilmu Komunikasi, 2 (2).

Opini Redaksi: Morat-Marit Menghadapi Corona. (2020). Majalah Tempo, 26.

Palupi, M. F. T., \& Irawan, R. E. (2020). Analisis Framing Pemberitaan Kebijakan Pemerintah Terkait Ketenagakerjaan sebagai Dampak Covid 19 di Kompas.com dan Malaysiakini. Jurnal Representamen, 6 (2), 8-22.

Pamella J., S., \& Reese, S. D. (1996). Mediating The Message. Theories of Influences on 
Mass Media Content Second Edition. Longman.

Sabir, A., \& M. Phil. (2016). Gambaran Umum persepsi masyarakat terhadap bencana di Indonesia. Jurnal Ilmu Ekonomi Dan Sosial, 5 (3), 304-326.

Sofian, A., \& Lestarini, N. (2021). Analisis framing pemberitaan tentang kebijakan pemerintah dalam menangani kasus Covid-19 (Analisis framing model Robert N. Entman pada media online Koran.tempo.co Edisi Maret 2020). Commicast, 2 (1), 5870.

Steele, J. (2007). Wars Within: Pergulatan Tempo Majalah Berita Sejak Zaman Orde Baru. Dian Rakyat.

Sulhan, M. (2020). Pupusnya Nilai Deliberatif dalam Keterbukaan Informasi Publik Penanganan Pandemi COVID-19. In S. Didik H., Nuruddin, \& F. Junaedi (Eds.), Tanggap Bencana Pandemi Covid-19 dalam Media Komunikasi dan Informasi di Masa Pandemi Covid-19. Mbridge Press.

Syaipudin, L. (2020). Peran Komunikasi Massa di Tengah Pandemi Covid-19 (Studi Kasus di Gugus Tugas Percepatan Penanganan Covid-19 Kabupaten Tulungagung). Kalijaga Journal of Communication, 2/No.1, 14-34.

Wibhisono, I. G. L. A. K. (2020). Framing Analysis of the Kompas' COVID-19 Coverage: $\begin{array}{lllll}\text { January } 2020 \quad \text { Edition. Jurnal } & \text { ASPIKOM, }\end{array}$ https://doi.org/10.24329/aspikom.v5i2.717

Widaningrum, A., \& Mas'udi, W. (2020). Dinamika Respons Pemerintah Nasional: Krisis Kebijakan Penanganan Covid-19. In W. Mas'udi \& W. Poppy S. (Eds.), Tata Kelola Penanganan COVID-19 di Indonesia: Kajian Awa. Gadjahmada University Press.

Wijaya, I. S. (2015). Perencanaan Dan Strategi Komunikasi Dalam Kegiatan Pembangunan. Lentera, 17(1), 53-61.

Yesicha, C., \& Irawanto, B. (2020). Dekonstruksi Wacana Subversif Meme \#IndonesiaTerserah. Jurnal Komunikasi Global, 9(2), 282-299. https://doi.org/10.24815/jkg.v9i2.17344

Zahrotunnimah. (2020). Langkah Taktis Pemerintah Daerah Dalam Pencegahan Penyebaran Virus Corona Covid-19 di Indonesi. Jurnal Sosial Dan Budaya Syar'i, 7 (3), 247-260. https://doi.org/10.15408/sjsbs.v7i3.15103

Zulaikha, N. H. (2019). Analisis Framing Pemberitaan Pilgub Jawa Timur 2018 pada Situs Berita Daring Indonesia. Communicatus Jurnal Komunikasi, 3 (1), 91-110. 